\title{
CIRUGÍA DE CÁNCER DE PULMÓN EN ESTADIO TEMPRANO EN LESIÓN CAVITARIA QUE SIMULABA ABSCESO PULMONAR, REPORTE DE CASO.
}

\author{
Macias Eddyn Ruben ${ }^{1}$, Iñahuazo Diana Margarita ${ }^{2 *}$, \\ Peñaloza Diana Elizabeth ${ }^{2}$, Garcés María de Lourdes ${ }^{2}$.
}

DOI: $10.48018 /$ rmv.v32.i1.S6

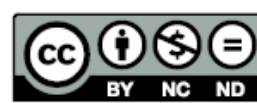

ste artículo está bajo una icencia de Creative Comicencia de Creative Com-
mons de tipo Reconocimiento - No comercial - Sin obras OPEN ACCESS derivadas 4.0 International.

1. Hospital de Especialidades Carlos Andrade Marín. Médico del Servicio de Neumología. Quito, Ecuador. 2. Universidad Central del Ecuador. Facultad de Ciencias Médicas. Posgrado de Neumología. Quito, Ecuador.

\section{ORCID ID:}

Macias Eddyn Ruben

orcid.org/0000-0002-1736-8501

Iñahuazo Diana Margarita

orcid.org/0000-0002-2165-5714

Peñaloza Diana Elizabeth

orcid.org/0000-0002-4883-785X

Garcés María de Lourdes

orcid.org/0000-0003-4055-457X

* Corresponding author:

Iñahuazo Diana Margarita

E-mail: danamish9027@gmail.com

Article history: Manuscript presented at the Clinical Case Contest - Hospital Vozandes Quito, February 27, 2021.

CARE 2017 Check List statement: The authors have real the CARE 2017 Check List and the manuscript was prepared and revised according to the CARE 2017 Checklist.

Conflict of interest: All authors declared that there are no conflicts of interest.

Financial disclosure: The authors have no financial relationships relevant to this article to disclose.

Forma de citar este artículo: Macias ER Iñahuazo DM, Peñaloza DE, Garcés ML. CIRUGÍA DE CÁNCER DE PULMÓN EN ESTADIO TEMPRANO EN LESIÓN CAVITARIA QUE SIMULABA ABSCESO PULMONAR, REPORTE DE CASO. Rev Med Vozandes. 2021; 32 (1 Suppl 1): S11-S12

\section{Resumen}

Introducción: Las cavitaciones pulmonares se definen como un espacio lleno de aire, dentro de una zona pulmonar de consolidación, una masa o de un nódulo, están producidas por la expulsión o el drenaje de la parte necrótica de la lesión a través del árbol bronquial. Las causas más frecuentes son infecciosas por micobacterias como en la tuberculosis, o bacterias como en la neumonía necrotizante, abscesos pulmonares, aunque en raras ocasiones, también se puede presentar en embolia pulmonar con infarto. Siempre se debe sospechar neoplasias, siendo el carcinoma escamoso el que se ha relacionado en mayor medida a lesion cavitaria pulmonar, y en menor medida en adenocarcinoma. Otras causas menos frecuentes son granulomatosis con poliangeitis, linfomas, neumoconiosis, silicosis.

Descripción del Caso: Paciente con sintomatología respiratoria de un año de evolución, caracterizada por tos con expectoración amarillenta esporádica más dolor torácico, en 03/2020 se acompaña de hemoptoicos y disnea progresiva, sin pérdida de peso, ni febrícula, facultativo particular indica antibiótico con mejoría parcial; en 08/2020 presenta hemoptisis, acude nuevamente a facultativo solicitan estudio tomográfico en el que evidencia cavitación pulmonar asociada a consolidación, administran nuevo esquema antibiótico, sin mejoría, acudiendo a esta casa de salud en 11/2020. Nuevo estudio tomográfico cavitación con paredes gruesas, función renal y hepática conservada, perfil infeccioso y pruebas inmunológicas negativas. Broncoscopia con citología de BAL positiva para malignidad, se indica tomografía simple y contrastada corporal y PET SCAN, evidenciando masa hipermetabólica en lóbulo inferior derecho, sin evidencia de metástasis a distancia, ni ganglios afectados. Se valora función pulmonar para resolución quirúrgica, siendo adecuada, se realiza lobectomía inferior derecha, evidenciando bordes quirúrgicos libres, con ganglios regionales negativos para malignidad, con patología que reporta adenocarcinoma de pulmón, estadiaje patológico T3NO, y de acuerdo al estudio imagenológico MO, determinando estadio IIB. Amerito quimioterapia y radioterapia de adyuvancia.

Conclusión: La sintomatología de cáncer pulmonar puede ser silente y principalmente inespecífica, en el estudio de Bradley et al. que aborda el riesgo de cáncer de pulmón por sintomatología y mediante radiografía de tórax, concluyen que la radiografía de tórax tiene sensibilidad limitada y que únicamente la hemoptisis tiene un valor predictivo estadísticamente significativo para malignidad. En relación a las lesiones cavitadas como presentación en cáncer de pulmón, se evidencian en el 5 al 15\% de todos los pacientes. Dentro de las neoplasias primarias la frecuencia con la que podemos observar cavitación de la lesión está en relación con el subtipo histológico, es más frecuente en carcinomas escamosos (9-38\%), más raro en adenocarcinomas (6-15\%) y carcinoma de células grandes, y prácticamente descarta carcinoma de células pequeñas.

Como conclusiones el manejo multidisciplinario permite adecuada orientación tanto en el algoritmo diagnóstico y terapéutico de los pacientes, que permitirá mejorar la sobrevida del paciente. 
Keywords: lung cavitation, lung cancer, early diagnosis, surgical management.

\section{Abstract \\ EARLY STAGE LUNG CANCER SURGERY IN CAVITARY LESION SIMULATING LUNG ABSCESS, CASE REPORT.}

Introduction: Pulmonary cavitations are defined as a space filled with air, within a pulmonary area of consolidation, a mass or a nodule, they are produced by the expulsion or drainage of the necrotic part of the lesion through the bronchial tree. The most frequent causes are infectious by mycobacteria as in tuberculosis, or bacteria as in necrotizing pneumonia, pulmonary abscesses, although on rare occasions, it can also present in pulmonary embolism with infarction. Neoplasms should always be suspected, being squamous cell carcinoma the one that has been related to a greater extent to pulmonary cavitary lesion, and to a lesser extent to adenocarcinoma. Other less frequent causes are granulomatosis with polyangiitis, lymphomas, pneumoconiosis, silicosis.

Case description: Patient with respiratory symptoms of one year of evolution, characterized by cough with sporadic yellowish expectoration plus chest pain, in 03/2020 is accompanied by hemoptysis and progressive dyspnea, without weight loss or fever, private physician indicates antibiotic with partial improvement; On 08/2020 she presented hemoptysis, she went to the doctor again and requested a tomographic study in which she showed evidence of pulmonary cavitation associated with consolidation, a new antibiotic scheme was administered, without improvement, and she went to this clinic on 11/2020. New tomographic study showed cavitation with thick walls, preserved renal and hepatic function, infectious profile and negative immunological tests. Bronchoscopy with BAL cytology positive for malignancy, simple and contrasted body tomography and PET SCAN were indicated, showing hypermetabolic mass in the right lower lobe, with no evidence of distant metastasis or affected lymph nodes. Pulmonary function is assessed for surgical resolution, being adequate, right lower lobectomy is performed, showing free surgical edges, with negative regional nodes for malignancy, with pathology reporting lung adenocarcinoma, pathological staging T3NO, and according to the imaging study $\mathrm{MO}$, determining stage IIB. He required chemotherapy and adjuvant radiotherapy.

Conclusion: Lung cancer symptomatology can be silent and mainly non-specific, in the study by Bradley et al. addressing lung cancer risk by symptomatology and by chest radiography, they conclude that chest radiography has limited sensitivity and that only hemoptysis has a statistically significant predictive value for malignancy. In relation to cavitated lesions as a presentation in lung cancer, they are evidenced in 5 to $15 \%$ of all patients. Within primary neoplasms the frequency with which we can observe cavitation of the lesion is related to the histological subtype, it is more frequent in squamous carcinomas (9-38\%), rarer in adenocarcinomas (6-15\%) and large cell carcinoma, and practically rules out small cell carcinoma.

As conclusions, multidisciplinary management allows adequate orientation in both the diagnostic and therapeutic algorithm of patients, which will improve patient survival. 